\title{
Determinants of Disclosure Quality: Empirical Evidence from Iran
}

\author{
NasrollahTakhtaei ${ }^{1}$ \\ Accounting Department, Islamic Azad University, Dezful Branch, Dezful, Iran \\ E-mail: nasrollah_takhtaei@yahoo.com
}

\begin{abstract}
Zahra Mousavi
Accounting Department, Islamic Azad University, Andimeshk Branch, Andimeshk, Iran E-mail: zmousavi62@gmail.com
\end{abstract}

Mohammad Tamimi

Assistant Professor, Accounting Department

Islamic Azad University, Dezful Branch, Dezful, Iran

E-mail: tamimi.mohammad@gmail.com

Iman Farahbakhsh

Accounting Department, Islamic Azad University, Dezful Branch, Dezful, Iran E-mail: if9087@yahoo.com

Received: Oct. 2, 2014 Accepted: Nov. 4, $2014 \quad$ Published: November 4, 2014

doi:10.5296/ajfa.v6i2.6693 URL: http://dx.doi.org/10.5296/ajfa.v6i2.6693

\begin{abstract}
In this study, we investigate whether quick assets ratio, current assets ratio, ROE, ROA, and financial leverage ratioas information disclosure quality determinants are related to information disclosure quality. Based on 240 Iranian firm-year observations over the period
\end{abstract}

\footnotetext{
1. Correspondence Author: Department of Accounting, Islamic Azad University, Dezful Branch, Dezful, Iran
} 
from 2006 to 2008 , we find that quick assets ratio is negatively and significantly associated with information disclosure quality, however current assets ratio, return on equity (ROE), return on assets (ROA), and financial leverage ratio are positively and significantly associated with disclosure quality.

Keywords: Information disclosure quality, Quick assets ratio, Current assets ratio, ROE, ROA, Financial leverage 


\section{Introduction}

After financial scandals of some reputation, huge corporations such as Enron and WorldCom that was followed decrease in common confidence in relation to the information and reports issued by these corporations, the more quality and more information was needed and has been resulted in more demand regarding more transparency, informativeness and reporting concerning corporations(Mashayekhi, 2007). More disclosure and transparency will result in long-run investments in behave of investors, more easily accessible to new capital, the least finance cost, more responsible and effective management and finally stocks higher price and considerable interests of shareholders(Bushman \& Smith, 2001). Research shows that corporation financial characteristics can affect their information disclosure quality. Therefore, this study aims to examine information disclosure quality effect on corporation's performance and capital structure. So, path and level of this effect is determined using correlation test, linear regression, and hence coefficients significance is tested.In this regard, theory fundamentals, literature review including theory fundamentals definitions, viewpoint and hypotheses relating to the subject and research experiment background, and the results of various researchers are presented. In research method section, research type, variables, population, sample selection and method used for the analysis are introduced and in the following section will have findings. Finally, the conclusion and suggestions will be presented.According to theory agency, when corporation's leverage level is higher, monitoring cost will be increased. Therefore, it is expected to be disclosing more information in order to decrease such a cost. Also, it is expected to be positive in the existence of such relationship.As a rule, it is expected to be disclosed more information in annual reports by corporations that total liabilities are higher in balance sheet(Ahmed \& Nicholls, 1994). For instance, a corporation with high ratio of liability to owners' equity (showing the corporation's financial leverage), more obligations have for the presenting information so that prepare creditor's needs and therefore may prepare more details in accounts and annual reports in order to prepare these needs than corporations with low high ratio of liability to owners' equity(Saghafi \& Malekiyan, 1997).

\section{Theoretical Framework and Literature Review}

In protecting shareholder value, agency theory and signalling theory assume that a complete, accurate and reliable disclosure should be provided to reduce information asymmetry, solve agency problems and reduce agency cost. From agency theory perspective, disclosure is one of the monitoring agents that aims to mitigate the agency cost in the principal-agent relationship(Hope \& Thomas, 2008; Jensen \& Meckling, 1976).Given that the principal-agent relationship leads to an agency problem, information asymmetry and conflict of interest, managers have incentives to provide a low quality of disclosure.Using Signalling theory, the authors justify this positive association by the fact that corporate managers of highly profitable companies are more likely to report more information to increase investors' confidence and consequently to raise their compensation and to raise capital at the lowest cost (Marston \& Polei, 2004). Agency theory also suggests that corporate managers of profitable companies have incentive to report more information to increase their compensation(Abd-Elsalam, 1999). 
Disclosure quality is difficult to measure because it is not directly observable (Lee, Petroni, \& Shen, 2006).Disclosure is defined as information released by a firm which may be financial or non-financial; qualitative or quantitative; mandatory or voluntary; disseminated through formal or informal channels(Gibbins, Richardson, \& Waterhouse, 1990). This definition of disclosure is broad and vague. However,previous studies define disclosure quality with various different keywords in practice. For example,Gray and Skogsvik (2004)explain that "voluntary disclosure supposedly provides information which goes beyond the requirements inherent in company law and the prevailing accounting standards" and "completeness, accuracy and reliability" is defined as disclosure quality bySinghvi and Desai (1971)andBrown and Hillegeist(2003)define quality of disclosure as "the precision, timeliness, and quantity of information provided". As stated byKent, Routledge, and Stewart (2010), "more extensive disclosures are likely to bemore informative than brief disclosures and are, therefore, an indicator of greatertransparency".

The quality of firm disclosure and firm financial and non-financial characteristics has become a subject of much interest in recent years and has attracted the interest of many major accounting journals.In a meta-analysis study, Ahmed and Courtis(1999)provide empiricalevidence that the association between corporate disclosure and profitability is differentand provides contradictory results.For example, they find that some studies(e.g., Singhvi \& Desai, 1971; R. S. O. Wallace, Naser, \& Mora, 1994)show asignificant and positive association, while others (e.g., McNally, Eng, \& Hasseldine, 1982; Raffournier, 1995)find no such anassociation. However, a statistically significant and negative association between the two variables have been found by Wallace and Naser(1996).Evidence from the previous empirical literature suggests that information asymmetrycan be reduced by increased disclosure(Brown \& Hillegeist, 2003; Coller \& Yohn, 1997; Glosten \& Milgrom, 1985; Petersen \& Plenborg, 2006; Welker, 1995). For example, Glosten and Milgrom(1985) have modeled the relationship between corporate disclosure and information asymmetry. Their model shows that information asymmetry decreases as the level of corporate disclosure increases. Welker (1995) providing empirical evidence indicates that information asymmetry is reduced as the level of disclosure isincreased.Using a sample of 19 Tunisian firms during the year 1999-2008, Riahi and Arab (2011) provide empirical evidence that disclosures that are associated with financial decisions and performance are beneficial in reducing managers' incentives to manipulate earnings. They find that disclosure transparency and disclosure of financial information shows statistically significant relationship.

\section{Methodology}

\subsection{Research design}

Akerlof (1970)stated that a well-run firm (with higher profitability and higher growth rates) would want to distinguish itself from lemon. It means that if the company is performing well its superiority can be signaled(Ross, 1977), information asymmetry between investors and managers reduced and agency costs reduced(Jensen \& Meckling, 1976) through increased disclosure. Different profitability and growth measures used have given contradicting signs for its association with disclosure quality(Laidroo, 2009). 
H1: there is a significant relationship between information disclosure quality and quick assets ratio.

H2: there is a significant relationship between information disclosure quality and current assets ratio.

H3: there is a significant relationship between information disclosure quality and return on equity.

Disclosure quality can also contribute to solve monitoring problems between creditors and shareholders and managers. Leverage may help reducing agency costs in relationship between owners and managers, since it engage managers to maximize the firms value and even to transfer wealth from creditors to shareholders(Kelly, 1983). Thus, an increase in disclosure quality should be used to give more confidence to creditors and reduce debt agency cost(Michaïlesco, 1999). Thus:

H4: there is a significant relationship between information disclosure quality and return on assets.

H5: there is a significant relationship between information disclosure quality and financial leverage ratio.

In line with previous studies, coefficient of determination and the regression coefficients are used to evaluate the relation between information disclosure quality and certain financial characteristics of listed firms on Tehran Stock Exchange. It is not possible to use time series in this research, so, considering the conditions in the study period, panel analyzing is used. Panel analysis is a combination of cross-sectional and time series. The panel balanced data model is applied in this research. The variables area combination of time series data and cross-sectional data for each sample firm, the covered time period is balanced and this is why we use panel data. The total framework of the panel statistical model is as follows:

$$
\begin{gathered}
Y_{i t}=\alpha+X_{i t}^{\prime} \beta+u_{i t} \\
u_{i t}=\mu_{t}+v_{i t} i=1,2, \ldots, n \quad t=1,2, \ldots, T
\end{gathered}
$$

$Y_{i t}=$ dependent variable

$X_{i t}=$ independent variables

$i=$ sampling observations (number of companies)

$t=$ number of time series observations

$\alpha, \beta=$ parameters of the model

The regression equation is estimated by generalized least square (GLS) regression method on the cross-section weights framework and also by using the cross-section fixed effects. 


\subsection{Sample selection}

The population of the study is accepted companies on the Tehran Stock Exchange (TSE) over the period from 2006 to 2008. These companies were selected without sampling and according to the following criteria including:1)the corporations must not be included in industries such as investment, holding, banking, and financial,2) in order to compare the corporations, firms' fiscal year must end on $20^{\text {th }}$ March (fiscal year end in Iran),3)the data and information concerning corporations must be available,4) firm's stocks have to be traded continuously on the Tehran Stock Exchange (TSE) and it does not stop more than one month.According to these criteria, 80 companies out of the total accepted corporations in Tehran Stock Exchange (TSE) were selected. The same procedure is applied for the years from 2006 to 2008 with a total of 240 companies out of the total population are chosen.

\subsection{Data collection}

In this study, we used the data collection using library method. In order to calculate the variables investigated, data needed that are related to the corporations' financial statements have been used from a variety resources such as Rahavard Database, Tadbirpardaz Database, Tehran Stock Exchange website and related compact disc (CD).For this reason, information regarding disclosure quality (DISCQUALITY) was collected first. Then data related financial ratios from financial statements accompanied notes were collect which entered into EXCEL and finally the hypotheses were tested and analyzed usingEviews 7.

\subsection{Variable definitions}

This section provides details of the measurement of my interest variables.

Table 1. Variable definitions

\begin{tabular}{ll}
\hline Variable name & Definitions \\
\hline Dependent & \\
DISCQUALITY & $\begin{array}{l}\text { Disclosure quality, measured by score assigned to the listed companies on TSE by } \\
\text { Tehran Stock Exchange. }\end{array}$ \\
Independent & Quick assets ratio, measured by (current assets - inventories) divided by current \\
QUICK & Liabilities \\
& Current assets ratio, measured by current assets divided by current liabilities \\
CURRENT & Return on equity, measured as net income divided by book equity \\
ROE & (Shareholder'sEquity) \\
ROA & Return on assets, measured by as net income divided by total assets \\
$L E V$ & Financial leverage ratio, measured by long-term liabilities divided by book equity \\
\hline
\end{tabular}




\subsection{Clasical Assumption Testing}

\subsubsection{Normality Testing}

The purpose of normality testing is to know that all data of independent and dependent variables have normal distribution. In this research, normality test is used based on Jarque-Bera test. $H_{0}$ would be accepted if the probability value of Jarque-Bera test is higher than $5 \%(\alpha=0.05)$, it means that all data have normal distribution. $H_{0}$ would be rejected if probability value of Jarque-Bera test is smaller than $5 \%(\alpha=0.05)$, it means that all data have not normal distribution.

\subsubsection{Multicollinearity Testing}

Multicollinearity is a condition in which one or more independent variables are in a linear contribution with other independent variables. It means that one or more independent variables correlate with other independent variables. Using correlation coefficients is one of the ways for identification of the Multicollinearity. It means that the existence large correlation coefficients between variables explanatory indicate the existence of Multicollinearity. In the other words, Multicollinearity testing can be analyzed from coefficient of correlation. This coefficient is criterion to measure the linear correlation between the two variables and do not use to describe the nonlinear relationship. This quantity is between the -1 and +1 values.

\subsubsection{Autocorrelation Testing}

When the residuals are correlated with each other over time, we are having autocorrelation problem. In this research, autocorrelation is tested usingDurbin-Watson test. If Durbin-Watson $(D-W)$ statistic value is between 1.5 and 2.5 values, it means that there is not a first order autocorrelation in the model. But if $D-W$ statistic value is smaller than 1.5 or it is higher than 2.5, it means that there is a first order autocorrelation in the model.

\subsubsection{Heteroscedasticity testing}

Heteroscedasticity occurs when variance disturbance is not consistent from one to another time at all observations. It can affect the estimates coefficient of regression, under-estimation, over-estimation or misleading. Heteroscedasticity testing uses a Baltagimethod, in which if the probability value is higher than $5 \%(\alpha=0.05)$, there is no heteroscedasticiy.According to Baltagi(2008), this may be a restrictive assumption for data panels, where cross-sectional units may often be of different size and sequence, and exhibit different variations.

\subsection{Hypothesis Testing}

In this research, there is one dependent variable correlated to five independent variables. Therefore, this research will be analyzed based on multiple linear regression,with the following equation:

$$
Y=a+b_{1} X_{1}+b_{2} X_{2}+b_{3} X_{3}+b_{4} X_{4}+b_{5} X_{5}+e
$$

Explanation: 
$Y=D I S C Q U A L I T Y$

$$
\mathrm{a}=\text { value of } Y \text { if } X_{1}, X_{2}, X_{3}, X_{4}, X_{5}=0
$$

$b_{1}, b_{2}, b_{3}, b_{4}, b_{5}=$ coefficients of regression

$X_{1}=Q U I C K$

$X_{2}=$ CURRENT

$X_{3}=R O E$

$X_{4}=R O A$

$X_{5}=L E V$

$\mathrm{e}=$ residual value

\subsubsection{First Hypothesis Testing}

First hypothesis is tested with F-test with the following formula:

$$
F=\frac{R^{2} /(k-1)}{1-R^{2} /(n-k)}
$$

Explanation:

$\mathrm{F}=\mathrm{F}$ value resulting from the calculation $\left(F_{\text {statistic }}\right)$

$R^{2}=$ coefficient of determination

$\mathrm{k}=$ number of variables

$\mathrm{n}=$ number of observations

The criteria of testing are as the following:

$H_{0}: b_{1}=b_{2}=b_{3}=b_{4}=b_{5}=0$ (quick assets ratio (QUICK), current assets ratio (CURRENT), return on equity (ROE), return on assets (ROA) and financial leverage (LEV) do not affect the disclosure quality (DISCQUALITY) simultaneously)

$H_{a}: b_{1}=b_{2}=b_{3}=b_{4}=b_{5} \neq 0$ (quick assets ratio (QUICK), current assets ratio (CURRENT), return on equity (ROE), return on assets (ROA) and financial leverage (LEV) affect the disclosure quality (DISCQUALITY) simultaneously)

Therefore, $H_{0}$ would be accepted if $F_{\text {statistic }}$ is smaller than $F_{\text {table }}$ (critical Value) or when the probability value is higher than $5 \%(\alpha=0.05)$, and $H_{0}$ would be rejected if $F_{\text {statistic }}$ is higher than critical value or when the probability value is smaller than $5 \%(\alpha=0.05)$.

\subsubsection{Second hypothesis testing}

Second hypothesis is tested by t-test with the following formula: 


$$
t=\frac{b_{j}}{S_{b_{j}}}
$$

Explanation:

$\mathrm{t}=\mathrm{t}$ value that is resulted from the calculation

$b_{j}=$ coefficient of regression

$\mathrm{S}_{\mathrm{b}_{\mathrm{j}}}=$ standard error of regression coefficient

The criteria of testing are as follows:

$\mathrm{H}_{0}: b_{1}, b_{2}, b_{3}, b_{4}, b_{5}=0$ (quick assets ratio (QUICK), current assets ratio (CURRENT), return on equity $(R O E)$, return on assets $(R O A)$ and financial leverage ( $L E V)$ do not affect the disclosure quality (DISCQUALITY) simultaneously)

$\mathrm{H}_{\mathrm{a}}: b_{1}, b_{2}, b_{3}, b_{4}, b_{5} \neq 0$ (quick assets ratio (QUICK), current assets ratio (CURRENT), return on equity $(R O E)$, return on assets $(R O A)$ and financial leverage $(L E V)$ affect the disclosure quality (DISCQUALITY) simultaneously)

Then, $H_{0}$ would be accepted if $t_{\text {statistic }}$ is smaller than critical value or when the probability value is higher than $5 \%(\alpha=0.05)$, and $H_{0}$ would be rejected if $t_{\text {statistic }}$ is higher than critical value or when the probability value is smaller than $5 \%(\alpha=0.05)$.

\section{Empirical results}

\section{1. Descriptive statisticsof variables}

Descriptive statistics of variables are presented in Table 2.

Table 2. Descriptive statistics

\begin{tabular}{lcccccc}
\hline & DISCQ & QUICK & CURRENT & ROE & ROA & LEV \\
\hline Mean & 54.13333 & 0.729042 & 1.252083 & 0.380542 & 0.157250 & 0.567458 \\
Median & 57.00000 & 0.680000 & 1.235000 & 0.340000 & 0.120000 & 0.600000 \\
Maximam & 100.0000 & 3.790000 & 3.790000 & 4.540000 & 2.070000 & 0.860000 \\
Minimum & 2.000000 & 0.040000 & 0.240000 & 0.010000 & 0.010000 & 0.170000 \\
Std. Dev. & 23.43474 & 0.466427 & 0.547433 & 0.358651 & 0.168996 & 0.141722 \\
Skewness & -0.254428 & 2.839173 & 1.408893 & 7.273606 & 6.939207 & -0.385093 \\
Kurtosis & 2.323912 & 17.45742 & 7.582596 & 79.04151 & 73.36717 & 2.303434 \\
\hline
\end{tabular}

Table 2shows that the average of disclosure quality (DISCQUALITY) for the corporations during period investigated, is 54.13. Additionally, we can see that score 2 as the least number of disclosure quality (DISCQUALITY) is very unfavorable for a corporation. The most important point in this table is high variance of disclosure quality. The fifthrow of table related to the standard deviation of variables is evident to this claim.Also, the mean of 


\section{Al Macrothink}

Asian Journal of Finance \& Accounting ISSN 1946-052X 2014, Vol. 6, No. 2

disclosure quality (DISCQUALITY), quick assets ratio (QUICK), current assets ratio (CURRENT), return on equity (ROE), return on assets (ROA) and financial leverage (LEV) are $54.13,0.72,1.25,0.38,0.15$ and 0.56 respectively.

Comparing the coefficient of variations $\left(\frac{S t d . D e v}{\text { Mean }}\right)$ of independent and dependent variables, indicative the amount of dispersion. It means that whatever the amount of dispersion of a variable is less, stability of that variable is further. Out of all the independent variables, $R O A$ has the greatest amount of dispersion (1.075) and $L E V$ has the lowest amount of dispersion (0.25). The difference between mean and median for the current assets ratio is lower than other variables, namely current assets ratio is more normal than other variables.

\subsection{Statistical Test Result of Classical Assumption Testing}

\subsubsection{Normality}

This research uses the analysis of Jarque-Beratest for normality testing. The result of normality test in table 3 , shows that the probability value of Jarque-Bera test is 0.06 , which is higher than $5 \%(\alpha=0.05)$. This indicates that all data have normal distribution.

Table 3 . The result of normality testing

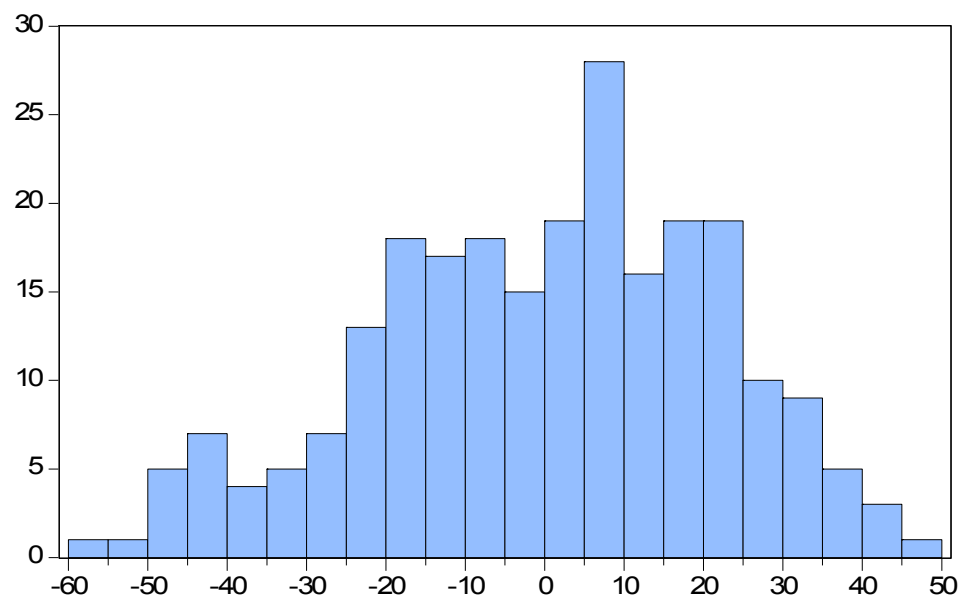

\begin{tabular}{|lr|}
\hline \multicolumn{2}{|l|}{ Series: Standardized Residuals } \\
Sample 1 240 \\
Obsenvations 240 \\
Mean & $-2.37 \mathrm{e}-16$ \\
Median & 3.302942 \\
Maximum & 47.58480 \\
Minimum & -55.42007 \\
Std. Dev. & 21.62584 \\
Skewness & -0.301360 \\
Kurtosis & 2.551261 \\
& \\
Jarque-Bera & 5.646381 \\
Probability & 0.059416 \\
\hline
\end{tabular}

\subsubsection{Multicollinearity Testing}

In this study, Multicollinearity testing is analyzed from coefficient of correlation. Correlation matrix between variables is displayed in table 4. According to the results, there is a little correlation between variables, suggesting absence of Multicollinearity. 
Table 4. Correlation Matrix

\begin{tabular}{llllll}
\hline & QUICK & CURRENT & ROE & ROA & LEV \\
\hline QUICK & $\mathbf{1 . 0 0 0 0 0 0}$ & & & & \\
CURRENT & 0.261052 & $\mathbf{1 . 0 0 0 0 0 0}$ & & & \\
ROE & 0.041951 & -0.002674 & $\mathbf{1 . 0 0 0 0 0 0}$ & & \\
ROA & 0.178049 & 0.207485 & 0.213563 & $\mathbf{1 . 0 0 0 0 0 0}$ & \\
LEV & -0.214620 & -0.296758 & -0.017367 & -0.255052 & $\mathbf{1 . 0 0 0 0 0 0}$ \\
\hline
\end{tabular}

Variables definition:QUICK: Quick assets ratio is measured as the(current assets - inventories) divided by current liabilities, CURRENT: Current assets ratio is measured as the current assets divided by current liabilities, ROE: Return on equity is measured as the net income divided by book equity (Shareholder'sEquity), ROA: Return on assets is measured as net income divided by total assets, $L E V$ : Financial leverage ratio is measured as the long-term liabilities divided by book equity.

\subsubsection{Autocorrelation Testing}

In this research, autocorrelation testing is used based on Durbin-Watson test.Result of $D-W$ test is displayed in table 6.It indicates clearly that the Durbin-Watson (DW) statistic value 2.13 which is between 1.5 and 2.5 values. This indicates that there is not a first order autocorrelation in the model.

\subsubsection{Heteroscedasticity Testing}

In this research, Baltagimethod is used totestheteroscedasticity. The results of this testing is displayed in table 5.It indicates clearly that prob-Fismore than0.05 in table 5 (0.77), suggesting no heteroscedasticity. 


\section{Macrothink}

Asian Journal of Finance \& Accounting

ISSN 1946-052X

2014, Vol. 6, No. 2

Table 5. Heteroscedasticity Testing

\begin{tabular}{|c|c|c|c|c|c|}
\hline \multicolumn{6}{|l|}{ ARCH Test: } \\
\hline \multicolumn{4}{|l|}{ F-statistic } & 0.072768 & probability \\
\hline \multicolumn{6}{|l|}{0.774822} \\
\hline \multicolumn{2}{|l|}{ Obs*R-squared } & & 0.073278 & & probability \\
\hline \multicolumn{6}{|l|}{0.774081} \\
\hline \multicolumn{6}{|l|}{ Test equation: } \\
\hline \multicolumn{6}{|c|}{ Dependent Variable: RESID`2 } \\
\hline \multicolumn{6}{|c|}{ Method: Least Squares } \\
\hline \multicolumn{6}{|l|}{ Sample: 2240} \\
\hline \multicolumn{6}{|c|}{ Included observations: 239 after adjustments } \\
\hline Variablecoefficient & Std.Error & t-Statistic & Prob & & \\
\hline $\mathrm{C}$ & 4236.642 & \multicolumn{2}{|c|}{1352.667} & \multicolumn{2}{|r|}{0.0015} \\
\hline $\operatorname{RESID}^{\wedge} 2(-1)$ & -0.014578 & \multicolumn{2}{|c|}{3.177022} & \multicolumn{2}{|r|}{0.7748} \\
\hline R-squared & 0.000212 & \multicolumn{2}{|c|}{0.052565} & -0.271705 & 4174.250 \\
\hline Adjusted R-squared & -0.002557 & \multicolumn{2}{|c|}{ Mean dependent var } & & 24070.42 \\
\hline S.E. of regression & 24112.86 & \multicolumn{2}{|c|}{ S.D. dependent var } & & 22.10484 \\
\hline Sum squared resid & $2.18 \mathrm{E}+11$ & \multicolumn{2}{|c|}{ Akaike info criterion } & & 22.11703 \\
\hline Log likelihood & -4028.877 & \multicolumn{2}{|c|}{ Schwarz criterion } & & 0.072768 \\
\hline \multirow[t]{2}{*}{ Durbin-Watson stat } & 2.000088 & F-sta & & & \multirow[t]{2}{*}{0.774822} \\
\hline & & \multicolumn{2}{|c|}{ Prob(F-statistic) } & & \\
\hline
\end{tabular}

\subsection{Statistical Test Result of Hypothesis Testing}

The output of multiple regression analysis is presented in the following table.

Table 6. The Result of Model Estimation

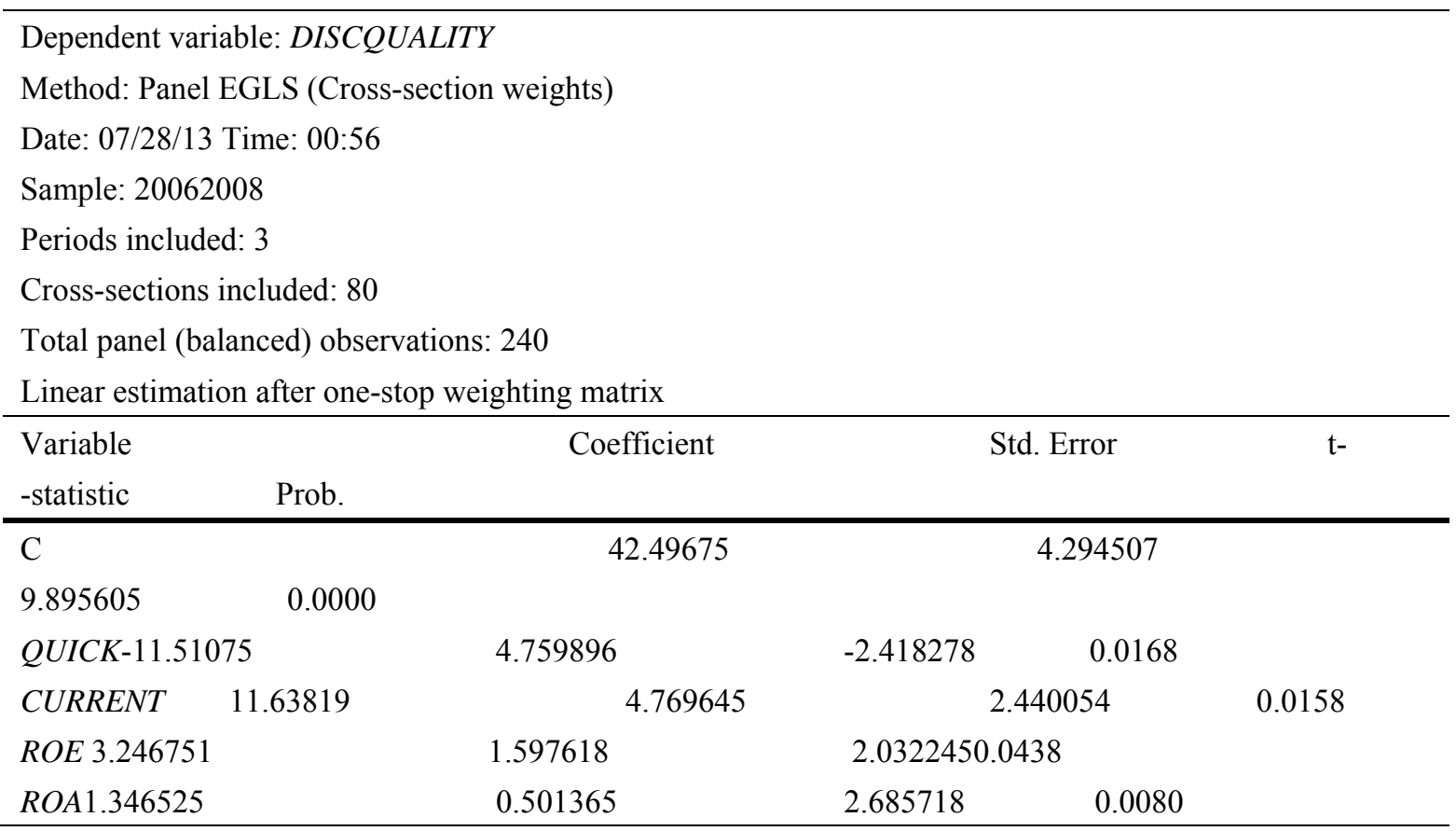




\section{Effects Specification}

\begin{tabular}{|c|c|c|c|}
\hline \multicolumn{4}{|c|}{ Cross-section fixed (dummy variables) } \\
\hline \multicolumn{4}{|c|}{ Weighted Statistics } \\
\hline R-squared & & & Mean dependent var126.2772 \\
\hline Adjusted R-squared & \multicolumn{3}{|c|}{ S.D. dependent var493.3059 } \\
\hline S.E. of regression & \multicolumn{3}{|c|}{ Sum squared resid44723.81 } \\
\hline F-statistic & \multirow{2}{*}{\multicolumn{2}{|c|}{222.5695}} & \multirow[t]{2}{*}{ Durbin-Watson stat } \\
\hline 2.138466 & & & \\
\hline Prob(F-statistic) & \multicolumn{2}{|l|}{0.000000} & \\
\hline \multicolumn{4}{|c|}{ Unweighted Statistics } \\
\hline $\begin{array}{l}\text { R-squared } \\
54.13333\end{array}$ & 0.994312 & & Mean dependent var \\
\hline $\begin{array}{l}\text { Sum squared resid } \\
2.865979\end{array}$ & 55373.58 & & Durbin-Watson stat \\
\hline
\end{tabular}

Based on table 6 , the regression equation is as follows:
DISCQUALITY $=42.49675-11.51075 * Q U I C K+11.638189 * C U R R E N T+3.246751 * R O E+1.34$ $6525 * R O A+7.811384 * L E V+[C X=F]$

\subsubsection{First Hypothesis Testing}

First hypothesis states that quick assets ratio (QUICK), current assets ratio (CURRENT), return on equity $(R O E)$, return on assets $(R O A)$ and financial leverage (LEV) affect the disclosure quality (DISCQUALITY) simultaneously. From the result of F-test, it is known that the calculation of $F$ results in (222.569) with the probability value of $(0.000)$ in which smaller than $5 \%(\alpha=0.05)$. This value is compared with the value on the $F$ table (critical value), i.e., 2.21. Since $F_{\text {statistic }}(222.569)$ is higher than that of critical value (2.21), and also the probability value of $(0.000)$ is smaller than $5 \%(\alpha=0.05)$, the firsthypothesis in this research is accepted. This indicates that our model is significant jointly with all variables investigated.

\subsubsection{Second Hypothesis Testing}

Second hypothesis states thatquick assets ratio (QUICK), current assets ratio (CURRENT), return on equity $(R O E)$, return on assets $(R O A)$ and financial leverage (LEV) affect the disclosure quality (DISCQUALITY) simultaneously. From the output of the regression, the result shows that:

4.3.2.1.Value of $t$-test for variable of quick assets ratio (QUICK)is 2.41higher than critical value (1.96), and the probability value of 0.016 is smaller than $5 \%(\alpha=0.05)$. It means that quick assets ratio (QUICK)affectssignificantly disclosure quality (DISCQUALITY) partially. 
4.3.2.2. Value of t-test for variable of current assets ratio (CURRENT)is 2.44higher than critical value (1.96), and the probability value of 0.015 is smaller than $5 \%(\alpha=0.05)$. It means that current assets ratio (CURRENT)affects significantly disclosure quality (DISCQUALITY) partially.

4.3.2.3.Value of $t$-test for variable of return on equity $(R O E)$ is 2.03 higher than critical value (1.96), and the probability value of 0.043 is smaller than $5 \%(\alpha=0.05)$. It means that return on equity (ROE) affects significantly disclosure quality (DISCQUALITY) partially.

4.3.2.4. Value of $t$-test for variable of return on assets $(R O A)$ is2.685higher than critical value (1.96), and the probability value of 0.008 is smaller than $5 \%(\alpha=0.05)$. It means that return on assets (ROA) affects significantly disclosure quality (DISCQUALITY) partially.

4.3.2.5. Value of t-test for variable of financial leverage $(L E V)$ is2.09 higher than critical value (1.96), and the probability value of 0.037 is smaller than $5 \%(\alpha=0.05)$. It means that financial leverage (LEV) affects disclosure quality (DISCQUALITY) partially.

According table $6, R^{2}$ and $\bar{R}^{2}$ show that approximately $65 \%$ of disclosure quality variations is explained by the independent variables. The result of $F$-test shows that $H_{0}$ is rejected at the $5 \%$ level and so the whole model is significant. The result of $t$-test shows that $H_{0}$ is rejected at the $5 \%$ level for independent variables, meaning that the coefficient sof these variables are significant. Durbin Watson $(D-W)$ statistic value (2.13) indicates that there is no first order autocorrelation in the model because the equation is estimated based on the weighted cross-section framework. Furthermore, heteroskedascity test indicates that the residuals variance is constant and Jarque-Bera test for normality testing indicates that residuals have been distributed normally.

\section{Conclusion}

The main purpose of this study is to investigate the relationship between information disclosure quality with quick assets ratio, current assets ratio, return on equity (ROE), return on assets (ROA), and financial leverage ratio. For this reason, 80 corporations out of total corporations in Tehran Stock Exchange were selected and analyzed during the period from 2006 to 2008. The results show that there is positive and significant relationship between information disclosure quality and current assets ratio, return on equity (ROE), return on assets (ROA), and financial leverage ratio. The existence of positive and significant association of information disclosure quality with current assets ratio, return on equity (ROE), return on assets (ROA), and financial leverage ratio indicates that corporations with higher current assets ratio, return on equity (ROE), return on assets (ROA), and financial leverage ratio have higher and appropriate information disclosure quality and vice versa. The results also show that there is positive and significant relationship between information disclosure quality and quick assets ratio. The existence of negative and significant association of information disclosure quality with quick assets ratio indicates that corporations with higher quick assets ratio have lower information disclosure quality and vice versa. Our investigation has remarkable implication for investors. Our study demonstrates that financial 
characteristics investigated in this study have approximately strong power in explaining information disclosure quality and investors may depend on this information regarding these variables disclosed by companies. However, investors also need to focus on the optimal mix of information disclosed by companies for achieving higher quality of financial reporting.

\section{References}

Abd-Elsalam, O. H. (1999). The Introduction and Application of International Accounting Standards to Accounting Disclosure Regulations of a Capital Market in a Developing Country: The Case of Egypt. (PhD Thesis), Heriot-Watt University, Edinburgh, UK.

Ahmed, K., \& Courtis, J. K. (1999). Associations between Corporate Characteristics and Disclosure Levels in Annual Reports: A Meta-Analysis. The British accounting review, 31(1), 35-61. http://dx.doi.org/10.1006/bare.1998.0082

Ahmed, K., \& Nicholls, D. (1994). The Impact of Non-Financial Company Characteristics on Mandatory Disclosure Compliance in Developing Countries: The Case of Bangladesh. The International Journal of Accounting, 29(1), 62-77.

Akerlof, G. A. (1970). The Market for" Lemons": Quality Uncertainty and the Market Mechanism. The Quarterly Journal of Economics, 84(3), 488-500. http://dx.doi.org/10.2307/1879431

Baltagi, B. (2008). Econometric Analysis of Panel Data (4 ed.): John Wiley \& Sons.

Brown, S., \& Hillegeist, S. A. (2003). Disclosure Quality and Information Asymmetry. Working Paper.

Bushman, R. M., \& Smith, A. J. (2001). Financial Accounting Information and Corporate Governance. Journal of Accounting and Economics, 32(1-3), 237-333. http://dx.doi.org/10.1016/S0165-4101(01)00027-1

Coller, M., \& Yohn, T. L. (1997). Management Forecasts and Information Asymmetry: An Examination of Bid-Ask Spreads. Journal of Accounting Research, 35(2), 181-191. http://dx.doi.org/10.2307/2491359

Gibbins, M., Richardson, A., \& Waterhouse, J. (1990). The Management of Corporate Financial Disclosure: Opportunism, Ritualism, Policies, and Processes. Journal of Accounting Research, 28(1), 121-143. http://dx.doi.org/10.2307/2491219

Glosten, L. R., \& Milgrom, P. R. (1985). Bid, Ask and Transaction Prices in a Specialist Market with Heterogeneously Informed Traders. Journal of Financial Economics, 14(1), 71-100. http://dx.doi.org/10.1016/0304-405X(85)90044-3

Gray, S. J., \& Skogsvik, K. (2004). Voluntary Disclosures of Quoted Pharmaceutical Companies in Sweden and the Uk: The Development over the Period 1984-98. European Accounting Review, 13(4), 787-805. http://dx.doi.org/10.1080/0963818042000216884 
Hope, O.-K., \& Thomas, W. B. (2008). Managerial Empire Building and Firm Disclosure. Journal of Accounting Research, 46(3), 591-626. http://dx.doi.org/10.1111/j.1475-679X.2008.00289.x

Jensen, M. C., \& Meckling, W. H. (1976). Theory of the Firm: Managerial Behavior, Agency Costs and Ownership Structure. Journal of Financial Economics, 3(4), 305-360. http://dx.doi.org/10.1016/0304-405X(76)90026-X

Kelly, L. (1983). The Development of A Positive Theory of Corporate Management's Role in External Financial Reporting. Journal of Accounting Literature, 2, 111-150.

Kent, P., Routledge, J., \& Stewart, J. (2010). Innate and Discretionary Accruals Quality and Corporate Governance. Accounting \& Finance, 50(1), 171-195. http://dx.doi.org/10.1111/j.1467-629X.2009.00321.x

Laidroo, L. (2009). Association between Ownership Structure and Public Announcements' Disclosures. Corporate Governance: An International Review, 17(1), 13-34. http://dx.doi.org/10.1111/j.1467-8683.2008.00717.x

Lee, Y.-J., Petroni, K. R., \& Shen, M. (2006). Cherry Picking, Disclosure Quality, and Comprehensive Income Reporting Choices: The Case of Property-Liability Insurers. Contemporary Accounting Research, 23(3), 655-692. http://dx.doi.org/10.1111/j.1467-8683.2008.00717.x

Marston, C., \& Polei, A. (2004). Corporate Reporting on the Internet by German Companies. International Journal of Accounting Information Systems, 5(3), 285-311. http://dx.doi.org/10.1016/j.accinf.2004.02.009

Mashayekhi, B. (2007). Transparency, Financial Accounting information and Corporate Governance. Corporate Governance Proceedings, Tehran Stock Exchange Corporation, 17-36.

McNally, G. M., Eng, L. H., \& Hasseldine, C. R. (1982). Corporate Financial Reporting in New Zealand: An Analysis of User Preferences, Corporate Characteristics and Disclosure Practices for Discretionary Information. Accounting and Business Research, 13(49), 11-20. http://dx.doi.org/10.1080/00014788.1982.9729725

Michaillesco, C. (1999). The Determinants of the Quality of Accounting Information Disclosed by French Listed Companies. EAA Congress, Bordeaux : France.

Petersen, C., \& Plenborg, T. (2006). Voluntary Disclosure and Information Asymmetry in Denmark. Journal of International Accounting, Auditing and Taxation, 15(2), 127-149. http://dx.doi.org/10.1016/j.intaccaudtax.2006.08.004

Raffournier, B. (1995). The Determinants of Voluntary Financial Disclosure by Swiss Listed Companies. European Accounting Review, 4(2), 261-280. http://dx.doi.org/10.1080/09638189500000016 
Riahi, Y., \& Arab, M. B. (2011). Disclosure Frequency and Earnings Management: An Analysis in the Tunisian Context. Journal of Accounting and Taxation, 3(3), 47-59.

Ross, S. A. (1977). The Determination of Financial Structure: The Incentive-Signalling Approach. The Bell Journal of Economics, 8(1), 23-40. http://dx.doi.org/10.2307/3003485

Saghafi, A., \& Malekiyan, E. (1997). Comprehensive Annual Reports and Financial Characteristics in Listed Companies on Tehran Stock Exchange The Iranian Accounting and Auditing Review, 22-23(1), 7-34.

Singhvi, S. S., \& Desai, H. B. (1971). An Empirical Analysis of the Quality of Corporate Financial Disclosure. The Accounting Review, 46(1), 129-138.

Wallace, R., \& Naser, K. (1996). Firm-Specific Determinants of the Comprehensiveness of Mandatory Disclosure in the Corporate Annual Reports of Firms Listed on the Stock Exchange of Hong Kong. Journal of Accounting and Public Policy, 14(4), 311-368. http://dx.doi.org/10.1016/0278-4254(95)00042-9

Wallace, R. S. O., Naser, K., \& Mora, A. (1994). The Relationship Between the Comprehensiveness of Corporate Annual Reports and Firm Characteristics in Spain. Accounting and Business Research, 25(97), 41-53. http://dx.doi.org/10.1080/00014788.1994.9729927

Welker, M. (1995). Disclosure Policy, Information Asymmetry, and Liquidity in Equity Markets. Contemporary Accounting Research, 11(2), 801-827. http://dx.doi.org/10.1111/j.1911-3846.1995.tb00467.x 